\title{
LETIER
}

\section{Identification and Analysis of Expression of Human VACM-1, a Cullin Gene Family Member Located on Chromosome 11q22-23}

\author{
Philip J. Byrd, ${ }^{1}$ Tatjana Stankovic, Carmel M. McConville, ${ }^{2}$ \\ Alexandra D. Smith, Paul R. Cooper, ${ }^{3}$ and A. Malcolm R. Taylor
}

CRC Institute for Cancer Studies, The University of Birmingham Medical School, Birmingham B15 2T], UK

\begin{abstract}
We have localized the human homolog of the rabbit vasopressin-activated calcium-mobilizing receptor VACM-1 to a region close to the gene for ataxia telangiectasia ATM on chromosome 1lq22-23. We have determined the complete amino acid sequence of the human Hs-VACM-1 protein, which is 780 amino acids long. The human and rabbit sequences are highly conserved, differing at only seven amino acids. Northern analysis of the human gene showed expression in a wide range of human tissues. The $H s-V A C M-1$ gene has homology with the Caenorhabditis elegans gene $\mathrm{Ce}$-cul-5, a member of a family of cullin genes that are involved in cell cycle regulation and that might, when mutated, contribute to tumor progression.
\end{abstract}

[The sequence data described in this paper have been submitted to GenBank under accession no. X81882.]

The gene for rabbit arginine vasopressin (AVP)activated calcium-mobilizing receptor $V A C M-1$ was isolated recently from a renal medullary cDNA library by expression cloning in Xenopus laevis oocytes (Burnatowska-Hledin et al. 1995). Expression of this novel gene in COS-1 cells produced an increase in high-affinity AVP binding and enhanced AVP-induced $\mathrm{Ca}^{2+}$ mobilization leading to elevated intracellular calcium concentrations. Analysis of the distribution of VACM-1 in rabbit kidney by immunofluorescent staining with anti-peptide antibodies showed that the protein was present in collecting tubule epithelia in both the renal medulla and the cortex. Additionally the pattern of immunoflourescent staining found in COS-1 cells transfected with a VACM-1 expression construct showed that VACM-1 protein was present on the cell surface, consistent with the identification of a putative transmembrane region in the amino acid sequence of the protein, and as expected of a peptide hormone receptor. The lack of any structural similarity to any previously identified receptor suggested that VACM-1 might be one of a new family of peptide receptors. More recently, however, VACM-1 was

\footnotetext{
'Corresponding author.

E-MAlL p.j.byrd@bham.ac.uk; FAX 0121-414-4486.

Present addresses: ${ }^{2}$ Institute for Child Health,University of Birmingham, Birmingham B16 8ET, UK; ${ }^{3}$ Department of Human Genetics, Roswell Park Cancer Institute, Buffalo, New York 14263.
}

found to have homology with a newly identified family of Caenorhabditis elegans genes, designated cullins, which are involved in the control of the cell cycle (Kipreos et al. 1996) and, because they contain putative nuclear targeting sequences and lack signal peptides or membrane-spanning domains, were purported to act intracellularly. Mutation of the $C$. elegans gene Ce-cul-1 causes hyperplasia in all tissues, and the mutant phenotype indicates that Cul-1 is required for cell cycle exit to the $\mathrm{G}_{0}$ state or for transition to an apoptotic pathway. By analogy with the Cul-1 phenotype it was suggested that mutation of mammalian cullin homologs might be implicated in clonal expansion and tumourigenesis (Kipreos et al. 1996).

In this paper we present the complete amino acid sequence of the human homolog for the rabbit VACM-1 gene and analyze the expression of this gene in a variety of different tissues.

\section{RESULTS}

While searching for expressed genes in the AT gene region on chromosome $11 \mathrm{q} 22-23$ we isolated an exon 6.82 that had no homology to any recognized gene but that matched an expressed sequence (Z21447) isolated from a testis cDNA library. This exon was used to identify several clones in arrayed human thymus and frontal cortex brain cDNA libraries, and the sequence of a long open reading 


\section{BYRD ET AL.}

frame was completed using additional clones from a human embryonic brain cDNA library and a hybridization selected clone derived from a lymphoblastoid cell line. The open reading frame was found to potentially encode a protein of 780 amino acids, the complete sequence of which is shown in Figure 1. The identity of this new human gene was revealed when the sequence of the rabbit (Oryctolagus cuniculus) VACM-1 receptor gene Oc-VACM-1 was released. This rabbit protein was found to have exactly the same number of amino acids as the protein encoded by the human gene that was identified by the 6.82 exon. Additionally the amino acid sequences of the two proteins were found to be $99 \%$ identical (Fig. 1), indicative of an important gene that had been highly conserved through mammalian evolution. A PCR assay for the 6.82 exon was also found to amplify the same sized product from human, monkey, dog, rabbit, and mouse but failed to amplify any bands from chicken or yeast (Saccharomyces cerevisiae) DNA (data not shown). This provided further evidence of the conservation of the $V A C M-1$ gene in mammalian evolution. The failure to amplify a product from chicken might be attributable to the evolutionary distance between mammals and birds or could be a reflection of the putative role of this gene in osmoregulation and differences in this process between mammals and birds.

The amino acid sequence of the human HsVACM-1 protein in Figure 1 is also shown in com-

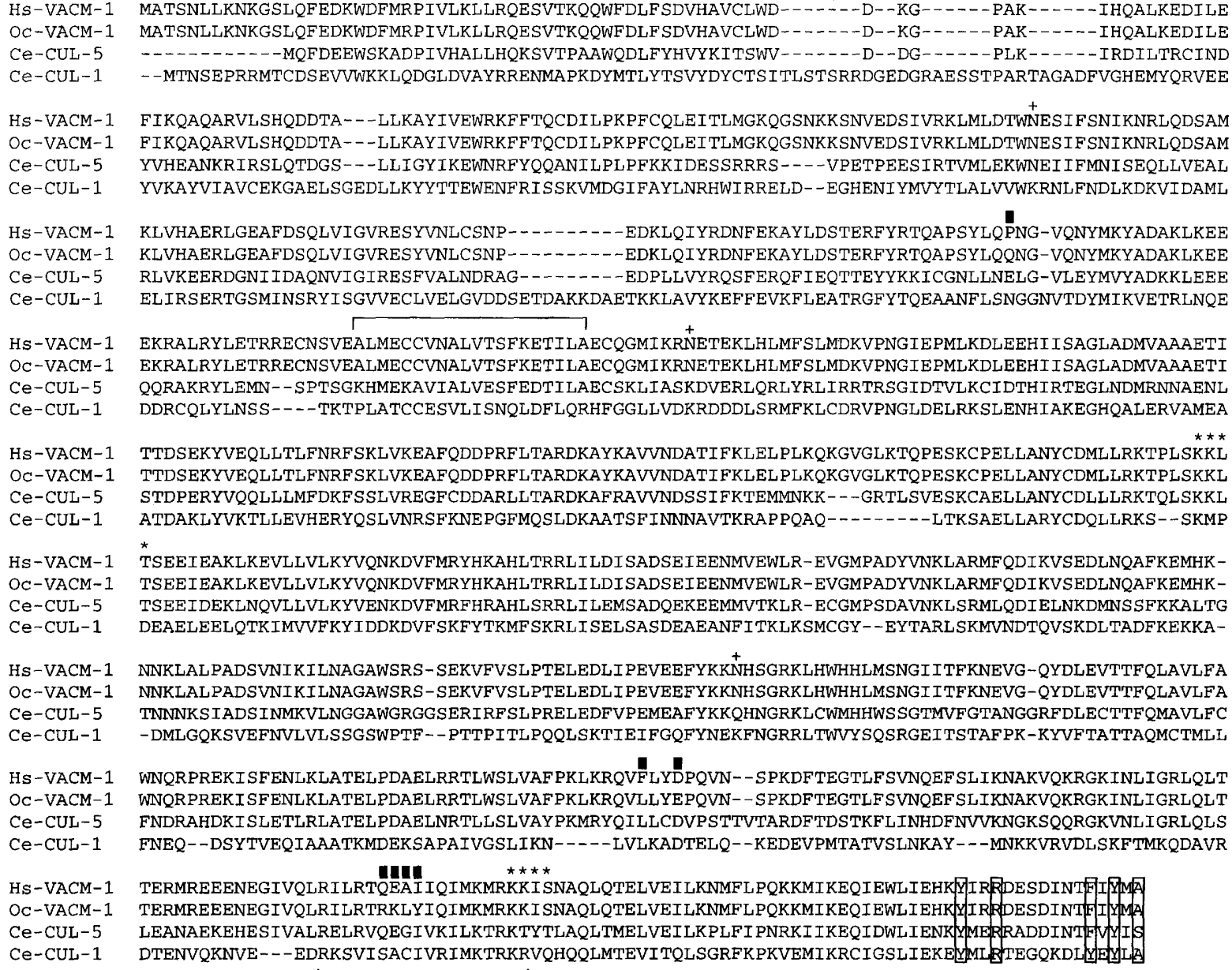

HS-VACM-1 Ce-CUL -5 Ce-CUL-1

$\mathrm{Hs}-\mathrm{VACM}-1$ Ce-CUL -5 Ce-CUL -5 OC-VACM-1 Ce-CUL-5 Ce-CUL-1

Hs-VACM-1 Ce-CUL-5 Ce-CULCe-CUL -1 作 QQRAKRYLEMN--SPTSGKHMEKAVIALVESFEDTILAECSKLIASKDVERLQRLYRLIRRTRSGIDTVLKCIDTHIRTEGLNDMRNNAENL

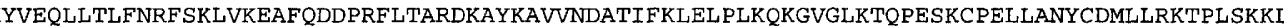
* TSEEIEAKLKEVLLVLKYVQNKDVFMRYHKAHLTRRLILDI SADSEIEENMVEWLR-EVGMPADYVNKLARMFQDIKVSEDLNQAFKEMHK作 DEAELEELQTKIMVVFKYI DDKDVF SKFYTKMF SKRLISELSASDEAEANF ITKLKSMCGY--EYTARLSKMVNDTQVSKDLTADFKEKKA-

作 TNNNKSIADSINMKVLNGGAWGRGGSERIRFSLPRELEDFVPEMEAFYKKQHNGRKLCWMHHWSSGTMVFGTANGGRFDLECTTFQMAVLFC -DMLGQKSVEFNVLVLSSGSWPTF--PTTPITLPQQLSKTIEIFGQFYNEKFNGRRLTWVYSQSRGEITSTAFPK-KYVFTATTAQMCTMLI

ORPREKISFENLKLATELPDAELRRTLWSLVAF PKLKRQVFLYDPQVN--SPKDFTEGTLFSVNQEF SLIKNAKVQKRGKINLIGRLQLT WNQRPREKI SFENLKLATELPDAELRRTLWSLVAF PKLKRQVLLYEPQVN- -SPKDFTEGTLFSVNQEFSLIKNAKVQKRGKINLIGRLQLT FNDRAHDKISLETLRLATELPDAELNRTLLSLVAYPKMRYQILLCDVPSTTVTARDFTDSTKFLINHDFNVVKNGKSQQRGKVNLIGRLQLS

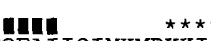
DTENVQKNVE- - EDRKSVI SACIVRIMKTRKRVQHQQLMTEVITQLSGRFKPKVEMI KRCIGSLIEKEYMIETEGQKDLY EVIS

Figure 1 The complete amino acid sequence of the protein encoded by the human Hs-VACM-1 gene and comparison to the rabbit VACM-1 and C. elegans CUL proteins. The putative transmembrane domain is overlined, and the hypothetical nuclear localization motif is underlined. Conserved residues that identify the tyrosine rich-motif at the carboxyl terminus of each protein are boxed. The amino acids in the human Hs-VACM-1 protein that differ to those in the rabbit Oc-VACM-1 protein are indicated by solid boxes above the amino acids. Putative cAMPdependent protein kinase $A$ phosphorylation sites are indicated by a series of asterisks above the site. Plus signs (+) above asparagine residues indicate potentially glycosylated amino acids. 
parison to those of the C. elegans Ce-CUL-1 and $\mathrm{Ce}-\mathrm{CUL}-5$ proteins. The $\mathrm{Ce}$-cul-1 gene was identified recently as a negative regulator of the cell cycle in $C$. elegans and is thought to act intracellularly, and perhaps intranuclearly on the basis of a potential bipartite nuclear targeting sequence. Ce-cul-5 is one of four additional related C. elegans genes that together with Ce-cul-1 form the cullin family of genes. Phylogenetically Ce-cul-1 and Ce-cul-5 were apparently separated at the earliest duplication of the ancestral gene and the branching of the cullin family, whereas the rabbit $O c-V A C M-1$ gene is most closely related to Ce-cul-5. As might be expected on the basis of the nearly identical sequence of the rabbit and human VACM-1 genes, the human gene is more closely related to Ce-cul-5 than it is to Ce-cul-1. The putative transmembrane domain encompassing amino acids 259-279 in the rabbit sequence (Burnatowska-Hledin et al. 1995) is perfectly conserved in the human protein (Fig. 1), as are the hypothetical protein kinase A phosphorylation sites at $\mathrm{Thr}^{426}$ and Ser- ${ }^{730}$ and the possible glycosylation sites at Asn- ${ }^{144}{ }^{\text {, Asn- }}{ }^{288}$, and Asn- ${ }^{565}$ (Burnatowska-Hledin et al. 1995). Of the 21 amino acids that comprise the putative transmembrane domain, 13 are conserved in Ce-CUL-5, compared to only 4 in Ce-CUL-1. The bipartite nuclear localization consensus motif ( 2 basic amino acids followed by 10 of any kind, then 3 basic residues in the next 5) postulated to be present in Ce-CUL-1 is not conserved in either VACM-1 protein or Ce-CUL-5. Interestingly this region contains 4 of the 7 amino acid differences between the VACM-1 proteins, and 3 of these 4 residues are conserved between human VACM-1 and Ce-CUL-5 (overall four of the seven amino acid differences are conserved between Hs-VACM-1 and Ce-CUL-5). All three proteins contain the conserved sequence of basic residues R-X-X-R- $\mathrm{X}_{9}-\mathrm{K}-\mathrm{X}-\mathrm{R}-\mathrm{K}$ in this region, which could perhaps represent a variant nuclear localization signal specific to this branch of the cullin family. The carboxyl terminus of the human protein contains the tyrosine-rich motif $\mathrm{Y}_{-} \mathrm{X}_{2}-\mathrm{R}-\mathrm{X}_{6-7}-\mathrm{Y} / \mathrm{F}-\mathrm{X}$ $\mathrm{Y}-\mathrm{X}-\mathrm{A} / \mathrm{S}$, which was noted as a striking feature of the ends of the C. elegans cullin proteins and OcVACM-1 (Kipreos et al. 1996).

We have submitted to the DNA database 3601 bp of $H s$-VACM-1 cDNA sequence (accession no. $\mathrm{X} 81882$ ) that contains $720 \mathrm{bp}$ of additional sequence at the 3 ' end relative to the published rabbit sequence, which ends in a poly(A) sequence. We have an additional 367 bp of imperfect sequence from the 5 -untranslated sequence that even in its incomplete state shows $75 \%$ identity with the 5 'untranslated sequence of the rabbit gene. Attempts to obtain additional 5 ' sequence by rapid amplification of cDNA ends (RACE) indicated that the sequence compiled from cDNA clones that were isolated from cDNA libraries was essentially complete. The $3968 \mathrm{bp}$ of sequence that we have at present would therefore seem to represent the complete $\mathrm{Hs}$ $V A C M-1$ sequence. Analysis of the expression of the Hs-VACM-1 gene in a variety of tissues, however, identified a major transcript of $\sim 7.5 \mathrm{~kb}$ (Fig. 2). Minor species of $\sim 4 \mathrm{~kb}$ were detected in skeletal muscle and heart, and there was a suggestion of additional species intermediate in size between the 7.7- and $4-\mathrm{kb}$ transcripts in skeletal muscle. The highest level of expression was found in skeletal muscle, with lower levels being apparent in all other tissues. Expression in kidney, the tissue from which the rabbit VACM-1 cDNA was cloned, was at the low levels found in other tissues.

\section{DISCUSSION}

In this report we present the complete amino acid sequence of the human VACM-1 gene and analyze the expression of this gene in 16 tissues. We identified the Hs-VACM-1 gene while searching for the gene for ataxia telangiectasia on chromosome 11q22-23 and have since mapped it (Stankovic et al. 1997) to a location immediately centromeric to the gene for mitochondrial acetoacetyl coenzyme A thiolase $(A C A T)$ and, according to the NotI restriction map developed by Arai et al. (1996), a minimum of $8.5 \mathrm{Mb}$ centromeric to the mixed lineage leukemia gene $M L L$. The amino acid sequence of the human VACM-1 protein was identical to that of its rabbit counterpart with the exception of 7 of the 780 amino acids that comprise each protein. Interestingly, 4 of the 7 residues that differ in the human protein are conserved in the nematode CUL- 5 cullin protein, in agreement with an earlier report in which the rabbit VACM-1 protein was found to be most closely related to the CUL-5 protein (Kipreos et al. 1996). The hypothetical transmembrane region identified in the rabbit protein is also completely conserved in the human gene. However, the significance of a single transmembrane motif has been questioned and the possibility that VACM-1 does not have a membrane-spanning domain has been raised (Kipreos et al. 1996). Common biochemical properties have been suggested for all cullin proteins on the basis of a conserved primary structure, and it has been claimed that all members of the family, including VACM-1, act intracellularly. Whether the putative nuclear localization motif is instrumental in directing CUL-1 protein to the 


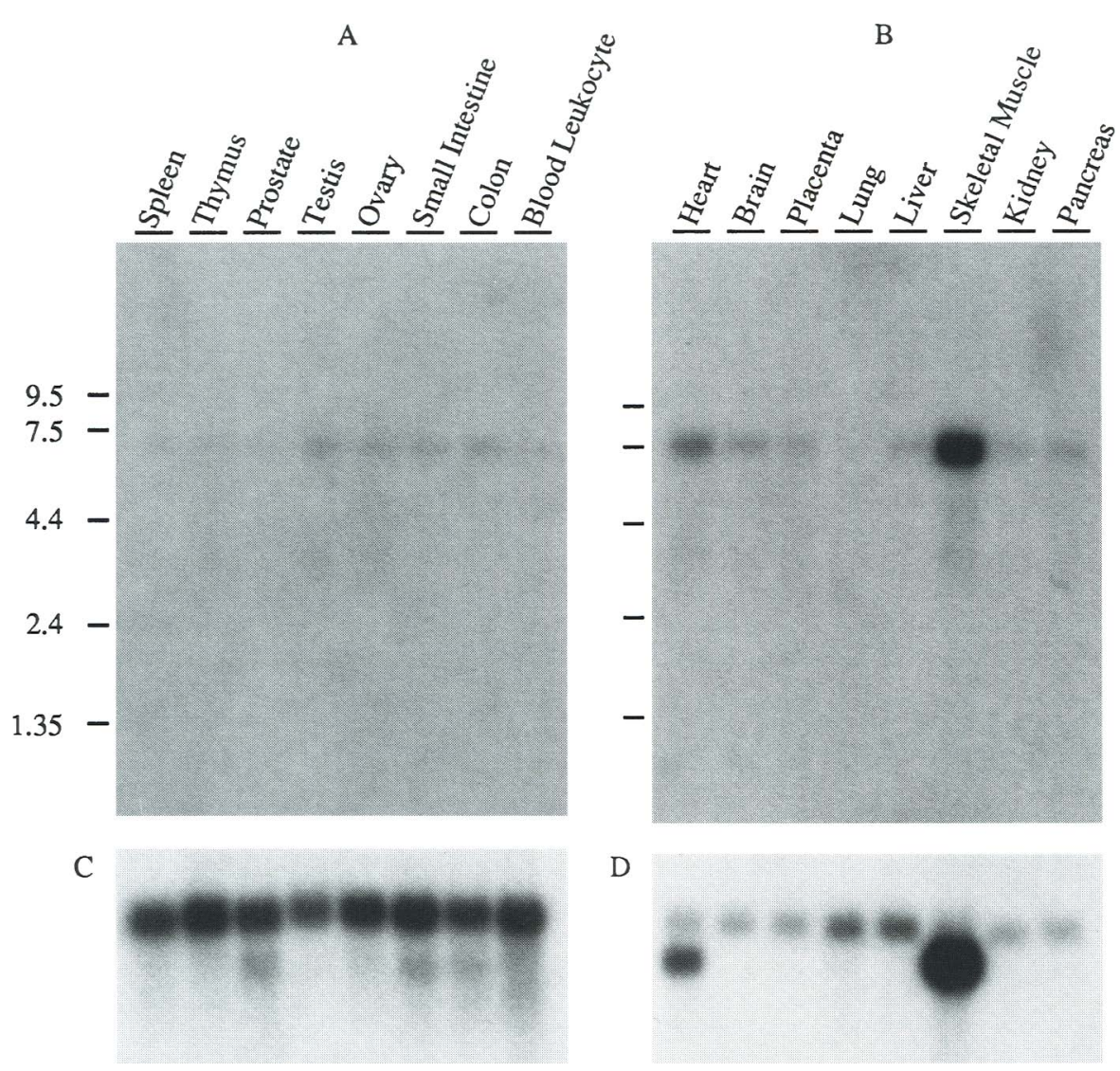

Figure 2 Analysis of Hs-VACM-1 mRNA transcription in human tissues. $(A, B)$ Nylon membranes containing electrophoretically separated poly $(A)^{+} \mathrm{RNA}(2 \mu \mathrm{g})$ from the indicated tissues that were hybridized with $\left[\alpha{ }^{32} \mathrm{P}\right] \mathrm{dCTP}$-labeled $\mathrm{Hs}$ $V A C M-1$ CDNA. $C$ and $D$ are the same membranes that were used in $A$ and $B$, respectively; but hybridized with radiolabeled $\beta$-actin DNA; the orders of the tissues are the same as shown in $A$ and $B$. Size markers shown at the left of $A$ and $B$ are in kilobases.

nucleus or some other cellular compartment is unknown. If the cullin family of proteins do have common biochemical properties, the lack of conservation of the nuclear localization motif in CUL-5 and the VACM-1 proteins suggests that this motif is not required for these functions.

Contrary to the assumption, on the basis of statistical sampling of expressed sequence tag (EST) libraries, that expression of the VACM-1 genes is restricted to certain tissues or stages of development (Kipreos et al. 1996), our analysis suggests that the human VACM-1 gene is transcribed in all tissues, albeit at a low level. The major transcript is at least $3 \mathrm{~kb}$ bigger than the $H s$-VACM-1 cDNA sequence that we have assembled. A similar observation was made in the rabbit by Burnatowska-Hledin et al. (1995), who found strong hybridization to an mRNA of $\sim 6.5 \mathrm{~kb}$. Our study indicates that there is little if any additional sequence remaining to be discovered at the $5^{\prime}$ end of the cDNA, suggesting that the outstanding sequence would most likely be from the $3^{\prime}$ end. We have already found $>700$ bp more $3^{\prime}$ untranslated sequence than was identified in the rabbit VACM-1 CDNA, and it has become apparent that there are many poly $(\mathrm{A})$ sequences in this sequence. Priming at these sites during cDNA synthesis may give an artificially low estimate of the length of the VACM-1 mRNA transcript.

The finding that the $\mathrm{Hs}$ VACM-1 gene is transcribed in all tissues indicates that a role for this gene in tumor progression should be considered, as highlighted for the cullin family in general by Kipreos et al. (1996). Our localization of the Hs-VACM-1 gene to human chromosome $11 \mathrm{q} 22-23$ is intriguing in the light of the loss of heterozygosity observed in breast cancer tumor samples at 11q22-23 (Carter et al. 1994; Hampton et al. 1994; Gudmundsson et al. 1995; Negrini et al. 1995; Tomlinson et al. 1995; Winqvist et al. 1995). Markers within the locus for the ataxia telangiectasia gene $A T M$ have recently been associated with this loss of heterozygosity, but no evidence was found of mutations in the remaining allele (Vorechovsky et al. 1996). Because this region of loss of heterozygosity extends centromeric to the $A T M$ gene and includes the region to which we have mapped the Hs-VACM-1 gene, this gene should now be considered as a possible tumor suppressor gene associated with breast cancer.

\section{METHODS}

\section{Construction of the Hs-VACM-1 cDNA Sequence}

A human fetal thymus cDNA library cloned in $\mathrm{MAX}$ (Clontech) was arrayed and pooled in a 96-well format for screening by PCR. An arrayed human frontal cortex cDNA library was also used in PCR screening. Clones specific to exons that were 


\section{HUMAN VACM-I, A CULLIN FAMILY GENE MEMBER}

trapped from cosmids derived from the AT region were identified and partially purified by PCR of the arrayed thymus and frontal cortex cDNA libraries, and isolated in a final hybridization step. Additional overlapping cDNA clones were obtained from a human embryonic brain cDNA library and by hybridization selection (Morgan et al. 1992; Futreal et al. 1994) from a human lymphoblastoid cell line, using sequences derived from AT gene region cosmids and YACs.

\section{DNA Sequencing}

The sequence of the $H s-V A C M-1$ cDNA was determined by direct sequencing of cDNA clones and by a vectorette sequencing strategy described previously (Byrd et al. 1996). cDNA clones and gel-purified, agarased PCR products were sequenced using an Applied Biosystems 373A DNA sequencer, and sequence assembly and analysis were performed using applications of the GCG program as described previously (Byrd et al. 1996).

\section{Analysis of $H s-V A C M-I$ Expression}

Multiple tissue Northern blots (Clontech) were hybridized with the complete $H s-V A C M-1$ cDNA sequence and washed according to the manufacturers recommendations. Hybridization signals were detected using Kodak X-OMAT AR film; exposures for up to 15 days were required to detect the weakest signals.

\section{ACKNOWLEDGMENTS}

We thank the Cancer Research Campaign, the Wellcome Trust and the A-T Research and Support Group for continued support.

The publication costs of this article were defrayed in part by payment of page charges. This article must therefore be hereby marked "advertisement" in accordance with 18 USC section 1734 solely to indicate this fact.

\section{REFERENCES}

Arai, Y., F. Hosoda, K. Nakayama, and M. Ohki. 1996. A yeast artificial chromosome contig and Not I restriction map that spans the tumour suppressor gene(s) locus, 11q22.2-q23.3. Genomics 35: 196-206.

Burnatowska-Hledin, M.A., W.S. Spielman, W.L. Smith, P. Shi, J.M. Meyer, and D.L. Dewitt. 1995. Expression cloning of an AVP-activated, calcium-mobilizing receptor from rabbit kidney medulla. Am. J. Physiol. 268: F1198-F1210.

Byrd, P.J., C.M. McConville, P. Cooper, J. Parkhill, T. Stankovic, G.M. McGuire, J.A. Thick, and A.M.R. Taylor. 1996. Mutations revealed by sequencing the $5^{\prime}$ half of the gene for ataxia telangiectasia. Hum. Mol. Genet. 5: 145-149.

Carter, S.L., M. Negrini, R. Baffa, D.R. Gillum, A.L. Rosenberg, G.F. Schwartz, and C.M. Croce. 1994. Loss of heterozygosity at 11q22-q23 in breast cancer. Cancer Res. 54: $6270-6274$.
Futreal, P.A., C. Cochran, J. Rosenthal, Y. Miki, J. Swenson, M. Hobbs, L.M. Bennett, A. Haugen-Strano, J. Marks, J.C. Barrett, S.V. Tavtigian, D. Shattuck-Eidens, A. Kamb, M. Skolnick, and R. Wiseman. 1994. Isolation of diverged homeobox gene, MOX1 from the BRCA1 region on 17q21 by solution hybrid capture. Hum. Mol. Genet. 3: 1359-1364.

Gudmundsson, J., R.B. Barkardottir, G. Eiriksdottir, T. Baldusson, A. Arason, V. Egilsson, and S. Ingvarsson. 1995. Loss of heterozygosity at chromosome 11 in breast cancer: Association of prognostic factors with genetic alterations. Br. J. Cancer 72: 696-701.

Hampton, G.M., A. Mannermaa, R. Winquist, M. Alavaikko, G. Blanco, P.J. Taskinen, H. Kiviniemi, I. Newsham, W.K. Cavenee, and G.A. Evans. 1994. Loss of heterozygosity in sporadic human breast carcinoma: A common region between 11q22 and 11q23. Cancer Res. 54: 4586-4589.

Kipreos, E.T., L.E. Lander, J.P. Wing, W.W. He, and E.M. Hedgecock. 1996. cul-1 is required for cell cycle exit in C. elegans and identifies a novel gene family. Cell 85: 829-839.

Morgan, J.G., G.M. Dolganov, S.E. Robbins, L.M. Hinton, and M. Lovett. 1992. The selective isolation of novel cDNAs encoded by the regions surrounding the human interleukin 4 and 5 genes. Nucleic Acids Res. 20: 5173-5179.

Negrini, M., D. Rasio, G.M. Hampton, S. Sabbioni, S. Rattan, S.L. Carter, A.L. Rosenberg, G.F. Schwartz, Y. Shiloh, W.B. Cavenee, and C.M. Croce. 1995. Definition and refinement of chromosome 11 regions of loss of heterozygosity in breast cancer: Identification of a new region at 11q23-24. Cancer Res. 55: 3003-3007.

Stankovic, T., P.J. Byrd, P.R. Cooper, C.M. McConville, D.J. Munroe, J.H. Riley, G.D.J. Watts, H.J. Ambrose, G.M. McGuire, A.D. Smith, A. Sutcliffe, T. Mills, and A.M.R. Taylor. 1997. Construction of a transcription map around the gene for ataxia telangiectasia; identification of at least four novel genes. Genomics (in press).

Tomlinson, I.P.M., J.E. Stickland, A.S.G. Lee, L. Bromley, M.F. Evans, J. Morton, and J.O'D. McGee. 1995. Loss of heterozygosity on chromosome $11 \mathrm{q}$ in breast cancer. J. Clin. Pathol. 48: 424-428.

Vorechovsky, I., D. Rasio, L. Luo, C. Monaco, L. Hammarstrom, A.D.B. Webster, J. Zaloudik, G. Barbanti-Brodano, M. James, G. Russo, C.M. Croce, and M. Negrini. 1996. The ATM gene and susceptibility to breast cancer: Analysis of 38 breast tumors reveals no evidence for mutation. Cancer Res. 56: 2726-2732.

Winqvist, R., G.M. Hampton, A. Mannermaa, G. Blanco, M. Alavaikko, H. Kiviniemi, P.J. Taskinen, G.A. Evans, F.A. Wright, I. Newsham, and W.K. Cavenee. 1995. Loss of heterozygosity for chromosome 11 in primary human breast tumours is associated with poor survival after metastasis. Cancer Res. 55: 2660-2664.

Received September 19, 1996; accepted in revised form December 3, 1996. 


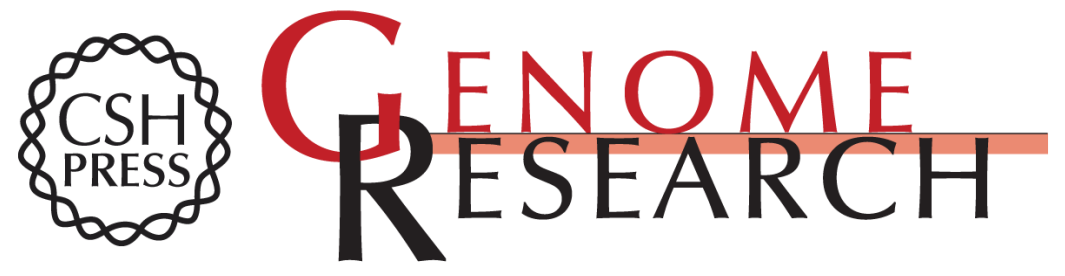

\section{Identification and analysis of expression of human VACM-1, a cullin gene family member located on chromosome 11q22-23.}

P J Byrd, T Stankovic, C M McConville, et al.

Genome Res. 1997 7: 71-75

Access the most recent version at doi:10.1101/gr.7.1.71

References This article cites 13 articles, 6 of which can be accessed free at:

http://genome.cshlp.org/content/7/1/71.full.html\#ref-list-1

\section{License}

Email Alerting Receive free email alerts when new articles cite this article - sign up in the box at the Service top right corner of the article or click here.

\section{Affordable, Accurate Sequencing.}

